\title{
Developing and implementing policy for the mandatory labelling of genetically modified food in South Africa
}

AUTHORS:

Taryn de Beer ${ }^{1}$

Rachel Wynberg ${ }^{1}$

\section{AFFILIATION:}

${ }^{1}$ Department of Environmental and Geographical Science, University of Cape Town,

Cape Town, South Africa

\section{CORRESPONDENCE TO:}

Taryn de Beer

EMAIL:

taryn.debeer@gmail.com

\section{DATES:}

Received: 25 Apr. 2017

Revised: 22 Dec. 2017

Accepted: 11 May 2018

Published: 30 July 2018

\section{KEYWORDS:}

GM food labelling; genetic modification; public participation; policy development; policy implementation

\section{HOW TO CITE:}

De Beer T, Wynberg R. Developing and implementing policy for the mandatory labelling of genetically modified food in South Africa. S Afr J Sci. 2018;114(7/8), Art. \#2017-0137, 7 pages. http://dx.doi.org/10.17159/ sajs.2018/20170137

\section{ARTICLE INCLUDES:}

$\times$ Supplementary material

$\times$ Data set

FUNDING:

National Research Foundation (South Africa)

(C) 2018. The Author(s). Published under a Creative Commons Attribution Licence.
Like many other countries, South Africa has come under public pressure to introduce mandatory labelling for genetically modified (GM) foods. Although there is increased understanding of the social and political implications of GM labelling in developed countries, implications for the Global South are still poorly understood. South Africa, as a country that consumes, produces and trades GM food, represents a fitting case study of these dimensions in the context of a developing economy. Via policy analysis, stakeholder interviews and document inquiry we offer an overview of the evolution of GM food labelling, investigate the central influences on its development and implementation, determine the critical issues and identify the factors impeding or facilitating implementation. Our findings reveal that many significant events and decisions influenced the policy on mandatory GM food labelling in South Africa. They also suggest that several pertinent and problematic issues arose during its development as a result of (1) the contentious nature of GM food labelling; (2) stakeholder opinions, influences, and conflicted positions; and (3) its practical complexity. Key implementation issues included divergent interpretations, and thus high levels of ambiguity; an inefficient National Consumer Commission; a lack of recourse for non-compliance; and the absence of a government-enforcement agency. Lower capacity in developing countries underscores the importance of a participation process that is believable by and inclusive of all actors. Stakeholders' opinions about the policy development process were affected by their predetermined viewpoints about GM organisms (GMOs). Findings emphasise the significance on participatory processes of larger policy debates about the acceptability of GMOs, and the importance of contextualising GM food labelling policies within such debates.

\section{Significance:}

- The first review of the evolution of mandatory GM food labelling policy in South Africa is provided.

- A knowledge gap with regard to GM food labelling in developing countries is filled.

- The importance of procedural fairness in determining the degree of stakeholder satisfaction with policy decisions is revealed.

\section{Introduction}

The labelling of genetically modified (GM) food is regarded as one of the most disputed food issues of the $21 \mathrm{st}$ century. ${ }^{1,2}$ As the land under GM crops has grown - reaching over 185 million hectares in 2016 from its inception in 1996 - GM food has increasingly entered our food chains. ${ }^{3}$ Worldwide, there is ongoing controversy over genetic modification, alongside consumer concerns about the safety and risks associated with GM food, both to human and animal health, and to the environment. ${ }^{4}$ This controversy placed public pressure on the European Union to introduce the first labelling policies for GM food in 2003. Since then, numerous other countries have introduced and implemented labelling legislation, policies, regulations or requirements for GM food. ${ }^{5}$ The characteristics of these approaches and the degree to which they are implemented differ significantly. ${ }^{2,6}$ Some countries have opted for a voluntary labelling approach, with guidelines, while almost 40 other countries, South Africa included, have approved mandatory labelling requirements. ${ }^{4,6}$

In a highly contested process, mandatory GM labelling was introduced in South Africa in 2009 through the Consumer Protection Act (No. 68 of 2008) (CPA), with associated regulations, which came into effect in 2011. Despite media attention ${ }^{7-13}$ there has been little research to explore the evolution of the policy process and its implementation. Moreover, although there is increased understanding of the social and political implications of GM food labelling in industrialised countries, those for countries of the Global South remain poorly comprehended. ${ }^{13}$ As a developing country that consumes, produces and trades GM food, South Africa is a fitting case study to fill this lacuna. We aim in this paper to provide an in-depth account of the development and implementation of GM food labelling policy in South Africa. As the policy's progression was examined and assessed, contentious and problematic issues were identified. Our investigation of these pertinent issues of GM food labelling in a developing country context can be used to inform and equip other developing countries that are considering mandatory labelling of GM foods. Through the analysis, we set out to suggest various possible improvements to South Africa's process of developing legislation by recommending that the government engage in best-practice participation for policy development.

\section{Methodology}

Policy development and implementation processes are complex and multifaceted and involve the participation of an array of stakeholders. To analyse these processes we used qualitative and quantitative research methods, framed around stakeholder perceptions. We collected, reviewed and analysed a range of relevant documents including emails, policy and legal documents, official government records, reports, press releases, newsletters, 
website materials and organisational publications. Most documents were obtained from the Department of Trade and Industry (DTI) through a request in terms of the Promotion of Access to Information Act, No. 2 of 2000 (PAIA) for access to the records of public bodies. In total, 429 documents were received.

Document analysis was complemented by semi-structured interviews, specifically tailored for different stakeholder groups, to draw out more considered, in-depth and complex responses. More than 100 stakeholders were contacted, identified by their engagement in the policy and through snowball sampling. Of these, 27 in-depth interviews were conducted with representatives from different sectors of society. These included the biotechnology and food industry (15), government (3), nongovernmental organisations (NGOs) (8), and the academic and scientific community (1). Interviews with stakeholders from consumer groups and trade unions were not conducted, as representatives from these two groups were not available. The stakeholders who were interviewed and are referenced throughout the paper (by superscript code) are listed in Table 1.

Table 1: Interviewed stakeholders

\begin{tabular}{l|l|l}
\hline $\begin{array}{c}\text { Respondent } \\
\text { code }\end{array}$ & \multicolumn{1}{|c}{ Respondent organisation } & \multicolumn{1}{|c}{ Interview date } \\
\hline ACB1 & $\begin{array}{l}\text { African Centre for Biosafety; now the } \\
\text { African Centre for Biodiversity }\end{array}$ & 31 January 2013 \\
\hline ACB2 & $\begin{array}{l}\text { African Centre for Biosafety; now the } \\
\text { African Centre for Biodiversity }\end{array}$ & 25 March 2013 \\
\hline AFB & AfricaBio & 20 March 2013 \\
\hline AGB & Agricultural Business Chamber & 1 February 2013 \\
\hline BIOW & Biowatch SA & 11 December 2012 \\
\hline CGC & Consumer Goods Council of South Africa & 30 January 2013 \\
\hline DOH & National Department of Health & 21 January 2013 \\
\hline DST & Department of Science and Technology & 23 January 2013 \\
\hline H\&H & $\begin{array}{l}\text { Hahn \& Hahn Inc. and Hahn \& Hahn } \\
\text { Attorneys }\end{array}$ & 26 March 2013 \\
\hline MON & Monsanto South Africa & 25 January 2013 \\
\hline SAF1 & $\begin{array}{l}\text { South African Freeze Alliance on Genetic } \\
\text { Engineering }\end{array}$ & 8 November 2012 \\
\hline SAF2 & $\begin{array}{l}\text { South African Freeze Alliance on Genetic } \\
\text { Engineering }\end{array}$ & 8 November 2012 \\
\hline & &
\end{tabular}

Questions were prepared and piloted prior to the interviews. These consisted of yes/no questions, choosing from lists, and ranking and rating. Topics ranged from knowledge of GM organisms (GMOs) in agriculture and GM food labelling to positions on GMOs in agriculture and on GM food labelling. Open-ended questions focused on policy development, implementation and compliance. Interview responses and document excerpts were analysed using coding and thematic analysis. Data were triangulated so as to verify sources and provide a comprehensive narrative of stakeholder participation. Participation was confidential and anonymous. Ethical clearance was obtained through the Faculty of Science Research Ethics Committee at the University of Cape Town (SFREC 37 2012).

\section{Development of a regulatory framework for GM food labelling}

South Africa has a history of strongly promoting modern biotechnology. ${ }^{14}$ Field trials for Bt cotton (referring to genes from the soil bacterium Bacillus thuringiensis which encode crystalline protein endotoxins that kill certain insect species) ${ }^{15,16}$ were first undertaken in 1992, followed by commercial plantings of GM cotton and maize. ${ }^{17,18}$ Eight years later, Bt white maize for human consumption (the staple food eaten by most South Africans) was commercialised..$^{17}$ In 2016, South Africa planted 2.66 million ha of commercial GM crops. ${ }^{3}$ Three of these GM crop types were: maize (2.16 million ha, or $90 \%$ of the country's production), soybean (494 000 ha, $95 \%$ of production) and cotton (9000 ha, 100\% of production). ${ }^{3,19} \mathrm{GM}$ canola may be imported as a commodity under a permit but may not be produced in the country. ${ }^{5}$ Commercially grown GM crops in South Africa, as in the rest of the world, comprise only two main traits: tolerance to the herbicide glyphosate, and pest resistance through incorporation of genes from Bacillus thuringiensis (Bt). Stacked traits, which combine two or more genes of interest into a single plant, are increasingly incorporated into GM seed, and maize in particular. ${ }^{19}$

Many South African consumers are unaware of the extent of GM crops in the country and of their own consumption of GM foods. 5,20 Although a small group of NGOs and consumer groups began lobbying for mandatory labelling when commercial production of GM crops commenced in 1997, South Africa only started to make provision for GM food labelling in 2004 - seven years later. ${ }^{7,21 ; \text { SAF1 }}$

Table 2 presents a chronology of the development of a regulatory framework for GM food labelling, setting out key milestones in the controversial history of this policy process. These milestones centred on (1) the adoption of voluntary labelling regulations in 2004 through the Foodstuffs, Cosmetics and Disinfectants Act No. 54 of 1972, administered by the Department of Health (DOH); (2) the promulgation of the CPA by the DTI in 2008, requiring mandatory labelling for GM goods, ingredients and components in food; and (3) regulations to give effect to the CPA.

\section{Introduction of proposals for GM food labelling}

In 2004, the DTI published a Green Paper on consumer policy, in which they proposed a new law to protect consumers and provided a first glimpse of proposals for GM food labelling. ${ }^{22}$ Voluntary labelling was subsequently introduced under the Foodstuffs, Cosmetics and Disinfectants Act, which required labelling if food differed significantly from its conventional (non-GM) counterpart in terms of nutritional composition, storage requirements, preparation or cooking, or if it contained an allergen or a human or animal gene.

Two years later, the draft Consumer Protection Bill was released for comment, and included a clause requiring the mandatory labelling of GM ingredients. The draft Bill also made provision for product liability, in terms of which any producer, distributor or supplier would be liable for any damage caused by their product, including that which might arise from consuming GM food.

The Bill was opposed by the Department of Agriculture, Forestry and Fisheries (DAFF) and the DOH, on the grounds that it would send out a confusing message to stakeholders. ${ }^{7,8,23,24}$ Concerns were also expressed about the cost of labelling and its impact on food prices, and the technical expertise required to ensure compliance. ${ }^{24}$ In response, the GM labelling clause was removed from the draft Bill in 2006, with a proposal to address policy issues under the Genetically Modified Organisms Act, No. 15 of 1997, and elsewhere. ${ }^{7,24}$ For the next two years, the South African Freeze Alliance on Genetic Engineering, an NGO network, campaigned to increase public awareness around GMO labelling ${ }^{25,26, \text { SAF1 }}$, mobilising a wide range of organisations to lobby the DTI to reinstate the labelling clause $\mathrm{e}^{7,25,26, \text { SAF } 1, \text { SAF2 }}$.

The first version of the Consumer Protection Bill [B 19-2008] that was introduced in Parliament in May 2008 confirmed the exclusion of GM labelling and also rendered those producing GMOs exempt from any liability for potential damage. ${ }^{27(561), 28}$ There were divergent stakeholder opinions as to why the labelling clause had been retracted. NGOs argued that a sudden turn of events had occurred, in which the industry had lobbied the Acting President to rescind the clause. ${ }^{\text {SAF1,AGB }}$ The industry's perspective was that GM labelling had never been envisaged for the CPA, and that the DTI, after consultation with industry members, believed it would be impractical to implement GM labelling and therefore withdrew it. ${ }^{\text {AGB,MON }}$ 
Table 2: Chronology of significant events and decisions during the policy development and implementation of mandatory GM food labelling in South Africa

\begin{tabular}{|c|c|}
\hline Date & Policy event \\
\hline 1992 & South Africa introduces the first field trials of GM crops. \\
\hline 1997 & The first commercial GM crops are grown in South Africa. The Genetically Modified Organisms Act 15 of 1997 (GMO Act) is promulgated. \\
\hline Early 2000s & The South African Freeze Alliance on Genetic Engineering begins lobbying for mandatory labelling of GM foods. \\
\hline 2004 & $\begin{array}{l}\text { Voluntary GM food labelling is introduced as Regulation } 25 \text { of } 2004 \text { under the Foodstuffs, Cosmetics and Disinfectants Act } 54 \text { of } 1972 \text {, } \\
\text { administered by the Department of Health. }{ }^{32} \text { The Department of Trade and Industry publishes a Green Paper on consumer policy, proposing a } \\
\text { new law to protect consumers. }{ }^{22}\end{array}$ \\
\hline March 2006 & A labelling clause is introduced in the draft Consumer Protection Bill (CPB). \\
\hline September 2006 & The labelling clause is removed from the CPB, with a proposal to address policy issues under the GMO Act and elsewhere. ${ }^{12,58}$ \\
\hline 2008 & $\begin{array}{l}\text { A clause is introduced in the CPB that exempts producers or suppliers of GMOs from liability. }{ }^{37,38} \mathrm{~A} \text { series of public hearings and provincial } \\
\text { briefings follows. }\end{array}$ \\
\hline April 2009 & $\begin{array}{l}\text { In response to concerns, the GM labelling clause is reinstated }{ }^{13,15,38} \text { and the Consumer Protection Act } 68 \text { of } 2008 \text { (CPA) is promulgated requiring } \\
\text { mandatory labelling for GM goods, ingredients or components in food. }{ }^{44} \text { Liability is also addressed. }\end{array}$ \\
\hline April 2011 & The CPA comes into effect. Regulations are promulgated. \\
\hline October 2011 & $\begin{array}{l}\text { Regulations governing the mandatory labelling of imported and locally produced GM foods come into effect, whereby goods, among other things, } \\
\text { are defined as 'anything marketed for human consumption'. }\end{array}$ \\
\hline 2011 & $\begin{array}{l}\text { An industry-aligned working group is established to help coordinate efforts and to interpret labelling regulations and compliance } \\
\text { measures. } \text {. }^{0, M O N, A G B}\end{array}$ \\
\hline 2012 & The National Consumer Commission develops a task team to draft GMO labelling guidelines. \\
\hline $2011-2012$ & Non-governmental organisations (NGOs) lay complaints for non-compliance with regulations. \\
\hline 2012 & The industry threatens litigation against NGOs. \\
\hline October 2012 & Draft amendments to the regulations are published for comment. \\
\hline July 2014 & The Department of Trade and Industry hosts a consultative conference. \\
\hline 2014 - present & The public comment period is extended, but amendments to the regulations have yet to be finalised. \\
\hline
\end{tabular}

A series of public hearings and provincial briefings followed, with several provinces, particularly the Western Cape, arguing for the reinstatement of the clause. ${ }^{28, A C B 2}$ This engagement was largely thanks to the efforts of the South African Freeze Alliance on Genetic Engineering. Their widespread consumer awareness outreach programme had made an impact, ${ }^{A F}, A G B, S A F 2, A C B 1$ alongside their testing of several random food products, which showed relatively high percentages of GM content. ${ }^{8}$ The Congress of South African Trade Unions (COSATU), the country's main trade union federation which forms part of the tripartite alliance alongside the governing African National Congress and the South African Communist Party ${ }^{17,29}$, also presented its case in support of mandatory labelling ${ }^{30}$. Without the support and influence from COSATU, GM labelling might well not have been included in the CPA. SAF1,ACB1

In an about-turn, the promulgation of the CPA saw the reinstatement of the GM labelling clause $e^{8,9,28}$, including mandatory labelling for GM goods, ingredients, or components in food ${ }^{31}$. The controversial liability clause was also removed, with liability for any harm caused by a defective product, irrespective of any negligence, now placed at the door of producer, importer, distributor or retailer of goods. ${ }^{28,32}$

Justifying this change of direction, the DTI noted that there were 'no substantial cost implications anticipated by introducing GMO labelling, as the Bill [did] not prescribe how labelling should be done'28. Opposition from the DOH, DAFF, the Department of Science and Technology (DST) and the food industry, remained, based on the cost of labelling and its impact on food prices, and the technical expertise required to ensure compliance. ${ }^{24 ; \mathrm{DST} T}$ The reinstatement of the clause was considered a great achievement by advocacy organisations and consumers, and 'a victory for consumer rights's(p.387).
Following a series of stakeholder workshops and an array of submissions ${ }^{21,32, A G B}$, regulations were promulgated in 2011 to give effect to the law. These regulations provided for the mandatory labelling of imported and locally produced GM foods, whereby goods, among other things, were defined as 'anything marketed for human consumption' 31 .

\section{Implementation of the Consumer Protection Act: 2011-2017}

A third phase of stakeholder involvement began after promulgation of the regulations. This phase included establishment of an industryaligned working group to help coordinate efforts and to interpret labelling regulations and compliance measures. ${ }^{33 ; \mathrm{MON}}$ Central concerns were to establish how to quantify the stipulated 5\% GM content and to clarify and define what was meant by 'contains at least $5 \%$ of GMOs'34,35. The industry appeared unanimous on the matter, and lodged complaints with the National Consumer Commission (NCC), seeking clarity on implementation. ${ }^{\text {MoN }}$ Inundated with requests, the NCC referred the matter to the Minister of Trade and Industry ${ }^{36}$ and, the NCC, together with an interdepartmental government task team (DOH, DAFF, DST and DTI), planned to help the industry by publishing guidelines.

Implementation challenges led to very low compliance initially by industry, especially regarding maize. ${ }^{36, \mathrm{MON}, \mathrm{DST}, \mathrm{DOH}}$ Two of South Africa's largest retail chains - Pick ' $n$ Pay and Woolworths - were among those advised by the commissioner to place implementation on hold until full consideration had been given to the issue. ${ }^{37}$ In turn, consumers were urged by NGOs such as the African Centre for Biosafety to lay complaints with the NCC for the labelling of GM food. . $^{38 \text { SAF2 }}$ In 2012, the African Centre for Biosafety carried out tests on several food products, with 
many testing positive for GMOs and with high levels of GM content - all were unlabelled. ${ }^{39}$ Biowatch South Africa achieved similar results that year, finding only one product with a compliant label. . $^{\text {Bow }}$ The four noncompliant companies were Nestlé, Pioneer Foods (Bokomo), Futurelife and Premier Foods. ${ }^{39}$

Considerable confusion arose about the scope and reach of the CPA. For example, the Consumer Goods Council of South Africa, on behalf of industry, sought clarity from the NCC on whether 'the members must label only the four varietals of maize, cotton, soybean and rape seed (canola), according to the provisions, or is it the intention that they label even products of which these varietals are ingredients or components? 'DST,DOH,AFB,H\&H Receiving no response, the Consumer Goods Council of South Africa assumed40,CGC the NCC's position to be that it would not enforce the Act as 'clarity [had] not been reached and all loopholes [had] not been closed'. ${ }^{40}$ Furthermore, a task team appointed by the commission to 'clarify all legal uncertainties and ambiguities, which may rise to interpretation problems' remained uncertain. ${ }^{\mathrm{CGC}}$ As such the Consumer Goods Council of South Africa advised its members not to label until they were given clarity. ${ }^{\mathrm{CGC}}$

Simultaneously, the African Centre for Biosafety and consumers lodged formal complaints with the NCC, after an undertaking to start labelling in the allotted time was breached by non-compliant companies. ${ }^{10,41}$ Several large food producers reacted by threatening legal action against the African Centre for Biosafety if claims continued that these companies were in contravention of the labelling law. ${ }^{11}$ Nestle and Pioneer Foods stated that they were 'fully compliant' and were 'waiting the outcome of a meeting between the NCC and industry representatives for a ruling on the GM labelling legislation'11. Premier Foods noted it would be 'phasing in new packaging for its mealie-meal to include GM labels'11.

Various stakeholders encountered obstacles with the NCC and blamed its failure on capacity, resource and capability constraints. 33;SAF2,DOH,AFB A number of technical issues also thwarted effective implementation. For example, a discrepancy was noted between the terminology 'genetically modified organism' used in the regulations and 'genetically modified ingredients or components of those goods' in Section 24(6) of the Act. ${ }^{41}$ To standardise terms, draft amendments to the regulations were published for public comment. ${ }^{42}$ These proposed that all local and imported food products, including processed products, containing $5 \%$ or more GM ingredients or components must be labelled as 'contains genetically modified ingredients or components' to enable consumers to make informed choices. ${ }^{43}$ Numerous comments were received on the amendments, but to date the amended GM labelling regulations have not been finalised. ${ }^{44}$

At present, the monitoring of the Act continues to rest largely on the shoulders of civil society organisations. ${ }^{\text {SAF1,AGB,BIOW }}$ While there is an increase in the number of food companies labelling products as GM, tests conducted on maize- and soya-based food products, including common maize meal and bread brands, reveal many labelling claims regarding percentage of GM content to be incorrect. ${ }^{12}$ Many of the tested products also remain unlabelled, with some containing high GM content. ${ }^{12}$

\section{Discussion}

The chronology described above reveals the critical role played by different stakeholders in the policy process. Prominent stakeholders included the biotechnology and food industries, government, NGOs, academia, trade unions and consumer organisations. Each played a role in agro-food politics and policymaking, forming part of networks or alliances in which there were mutually understood interests and values. For the most part they reflected the conflicting positions of pro-GMO lobbyists, the anti-GMO network and other actors, such as those in government, who formed their own sets of alliances with these networks. ${ }^{45}$

However, the polarisation of views and positions occurred not only between industry, researcher and NGO interest groups, but also between certain government departments, which in turn created difficulties in reaching a consensus. ${ }^{29,46 ; 0 \mathrm{OH}} \mathrm{A}$ central tension arose between a policy position supporting voluntary labelling and limited liability for those manufacturing GM foods, versus one advocating mandatory labelling. Although the liability clause was later amended, the challenges of implementing mandatory labelling and a lack of clarity about the scope and reach of the CPA presented a further set of issues, accompanied by low levels of compliance by industry. ${ }^{36}$

\section{Consultation or active participation?}

The question remains as to whether the process was inclusive, fair and consultative, or exclusive, unfair and conflictual. The complex, dynamic, uncertain and multiscalar nature of today's environmental problems, as well as the various stakeholders and organisations they affect, calls for 'flexible and transparent decision-making that embraces a diversity of knowledge and values'. ${ }^{47(0.2417)}$ Consequently, stakeholder participation has gradually become more entrenched in environmental decisionmaking, across national and international policies. ${ }^{47(0.2417)}$. Policies which have successfully incorporated a stakeholder guided approach to their development, especially those intended to protect the environment and public interests, hold important lessons for GM labelling in South Africa.

Rowe and Frewer $^{48}$ describe a typology of stakeholder engagement focused on the 'nature', instead of the 'degree', of participation. ${ }^{48}$ This defines different forms of public engagement by the way in which 'communication migrates'. .8(p.2419) $^{2}$ Collecting or soliciting input from participants is deemed 'consultation', while 'active participation' is seen as a two-way communication, with information exchanged through dialogue or bargaining. ${ }^{48(p .2419), 51}$

In the GM labelling process, document analysis reveals that the term 'consultation' was used repeatedly by stakeholders, and refers to the gathering of information during the public hearings and providing comments on published drafts. Other more participatory mechanisms used included workshops, meetings and conferences, which opened up spaces for dialogue and more meaningful interaction. Innes and Booherer(p.426) assert that involving stakeholders to 'jointly recommend regulations', as in this case, is part of a collaborative participation process. Rowe and Frewer ${ }^{48}$ call it 'active participation'. Active participation implies a process that is inclusive of stakeholders and places dialogue at the centre, rather than one that merely produces comments on already set-down proposed regulations. We can conclude that both consultation and active participation mechanisms - with open dialogue and two-way information exchange - were used by the government, through the DTI, during the participation process in developing policy governing the labelling of GM foods.

\section{Inadequate representation}

It is well recognised that the full range of stakeholders should be represented in policy development to lessen the probability that those on the 'periphery of the decision-making context or society are marginalised' ${ }^{47(0.2420)}$ This full range was not realised during the development of the mandatory labelling policy, with inadequate representation of farmer organisations and consumer groups. As noted by Parkins and Mitchell ${ }^{50}$, such exclusions can well weaken such a process. In addition, representation in the process was restricted to a reduced set of interests comprising industry, government and NGOs that held a stake in and/or had knowledge of GM food labelling and dominated the policy space. ${ }^{50,51}$

An interesting exception was the mobilisation of public interest NGOs to represent the diffuse and under-represented interests of consumers, and to ensure that there was a balance of lay versus expert participation. ${ }^{51}$ As noted by Aerni52(p.465), the involvement of public interest groups in 'protest events...attracts the attention of the mass media and build[s] up public pressure on politicians to respond to [their] concerns'. Clearly, public opinion can influence and shape politics in developing countries such as South Africa, although, as Aerni52(p.465) argues, it may well be 'the opinion of academic, political, economic and traditional elites rather than the public at large that matters in such elite democracies'. In Kenya, for example, the food industry and politicians dominated the policy space by opposing new mandatory labelling regulations, cautioning that such labelling could raise food prices and reduce food security in the country. ${ }^{43}$ 


\section{Perceived fairness polarised}

Herian et al..$^{53}$ confirm that citizens who are given information about public participation procedures during policy development perceive the process to be fairer. If the participatory mechanisms used are believed to be 'transparent and consider [all the] conflicting claims and views', this could then boost 'public trust in decisions and civil society' ${ }^{\text {'7(p.2.2420). }}$

In the case of GM labelling in South Africa, interesting schisms developed between NGOs and the industry, and, significantly and unusually, between government departments themselves. For example, the $\mathrm{DOH}$ and the DST, as well as the industry, distrusted the DTI, believing the process had not always been transparent, and that their views and input had not been considered. The weak and even dissonant relationships between the industry and the DTI, as well as between the DTI and other government departments, added to perceptions that the policy process had been unfair. NGOs, in contrast, perceived the process to have been transparent, for the most part, as they believed that they had been 'listened' to, and that their views and inputs had been considered. This belief enhanced trust in decisions and policymakers. ${ }^{47}$

While it is clearly important for public participation processes to be fair, transparent and inclusive, it is telling that perceptions of procedural fairness were limited to policy outcomes, rather than the policy process itself. This suggests that if schisms on controversial issues such as GMOs are not resolved prior to policymaking, then participatory measures in developing policies are doomed to fail from the start.

\section{Towards improved policy development}

Given the contested nature of GM food labelling, it is appropriate to ask what approaches might have worked better. A more deliberative democratic participatory policy process might have transformed the adversarial relationships between stakeholders. Many stakeholders, for example, reported experiencing consultation fatigue, because of perceptions that their involvement was ineffectual and had limited capacity to 'influence decisions' $47($ (p.2420). The consultations were believed to be 'talk shops', which produced uncertainty and hindered definitive activity.47(p.2420) The conflict between certain stakeholders obstructed authentic participation and discussion and resulted in ambiguity and delayed decisive collective action or consensus.

Democratic participation, as observed by Parkins and Mitchell ${ }^{50}$, is where participation is restricted to 'voting and where public deliberation is severely limited to issue "sound bites" and popularity contests"50(p.530), which occur, for example, during public hearings. Under such circumstances, greater attention could have been given to creating deliberative spaces that deepened the discourse, improved the quality of decisions and produced concepts and knowledge that enhanced both expertise and understanding. As noted by Chambers (2003, cited in Parkins and Mitchell ${ }^{50}$ ), deliberative democratic participation offers and solicits debate and dialogue that can bring about rational, knowledgeable views, in which the participants are prepared to amend preferences in view of 'discussion, new information, and claims made by fellow participants'50(p.530). By offering a collaborative and deliberative democratic participation process, the DTI could have provided an opportunity for meaningful stakeholder debate, personal reflections and an exchange of informed stakeholder opinion - an approach that could have transformed adversarial relationships between the stakeholders. An alternative and more cynical view is that any process would have met with resistance, because stakeholder positions and interests were founded on principle more than rationality. If stakeholders are not willing to negotiate their positions and interests and identify common objectives, then conflictual relationships will not be transformed.

There were certainly elements of the process that could have been improved. For example, the DTI could have replaced their 'tool-kit approach', which stresses picking the applicable tools for the task, with a method that looks at 'participation as a process'. This approach might have taken into account how to involve relevant stakeholders, the most suitable time to do so, and approaches for stakeholders to 'fairly and effectively shape environmental decisions'.47(p.2422) Bestpractice participation can ensure that stakeholders have the power to influence policy decisions and have the technical competence to engage effectively. ${ }^{47(0.2422), 53-55}$ This issue is relevant to both developed and developing economies, which share poor knowledge about GMOs, but is likely exacerbated in a developing country context with low levels of literacy. ${ }^{20}$ In this regard, efforts could be made to educate stakeholders, and develop their understanding and confidence.

Early interventions prior to the setting of policy, which could include one-on-one interactions, and active in-depth engagement between stakeholders and policymakers, would certainly help to strengthen the process, both through its design and stakeholder involvement. As noted by Reed ${ }^{47}$, if participatory processes are to bring about 'high quality and durable decisions', then stakeholder engagement from the very start of the process is critical. ${ }^{56,57} \mathrm{~A}$ stakeholder analysis is an important first step to methodically identify and represent those actors relevant to the decision-making processes. ${ }^{47,57}$ The level of participation in the analysis should extend to active engagement in which there is a two-way transfer of information between stakeholders and policymakers. ${ }^{47}$

\section{Conclusions}

Stakeholders have a democratic right to participate in environmental decision-making, such as the policymaking process of mandatory GM food labelling in South Africa, as this policy could affect their everyday lives. At present, the CPA mandates the labelling of all GM foods in South Africa, because of a belief that a policy is needed to protect the rights of consumers. The findings of this paper, which are in line with Herian et al. ${ }^{53(p .1)}$, show that perceptions of procedural fairness among stakeholders are a strong predictor of satisfaction with policy decisions. Similarly, the extent to which positions are accommodated influences perceptions on procedural fairness. Those that lobbied for labelling - NGOs and consumers - largely believed the process to be fair and inclusive, as well as consultative, although this view changed when their interests were not addressed. In a similar vein, those stakeholders against labelling - the industry, DAFF, DOH and DST - perceived the process to be fair when their point of view was accommodated, but unfair and exclusive, and the DTI's activities to be unacceptable, when their positions were not incorporated. Lower levels of capacity in developing countries, both with regard to the technical considerations of GM crops and the implementation of labelling legislation, underscore the importance of a public participation process that is believable by and inclusive of all actors. Our findings also emphasise the need to resolve larger policy questions regarding the adoption or rejection of GMOs, before the start of the participatory process.

\section{Acknowledgements}

We thank all those who took the time to participate in this research for their invaluable input. The DTI supplied a documentary record for mandatory GM labelling with 429 documents received through a PAIA request. This work is based on research supported by the South African Research Chairs Initiative of the Department of Science and Technology and National Research Foundation of South Africa. Any opinion, finding and conclusion or recommendation expressed in this material is that of the authors and the NRF does not accept any liability in this regard.

\section{Authors' contributions}

T.d.B. conducted the research under the supervision of R.W. The research was co-conceptualised and co-written by both authors. The grant that enabled the research was held by R.W.

\section{References}

1. Klintman M. The genetically modified (GM) food labelling controversy: Ideological and epistemic crossovers. Soc Stud Sci. 2002;32(1):71-91. https://doi.org/10.1177/0306312702032001004

2. Bansal S, Ramaswami B. Labels for GM foods: What can they do? Econ Polit Wkly. 2010;45:26-27.

3. James C. Global status of commercialized biotech/GM crops. ISAAA brief no. 52. Ithaca, NY: International Service for the Acquisition of Agri-biotech Applications (ISAAA); 2016. 
4. Zainol ZA, Nordin R, Akpoviri FI. Mandatory labelling of genetically modified (GM) foods. Int Environ Agreem-P. 2015;15(2):199-216. https://doi. org/10.1007/s10784-013-9230-5

5. Viljoen CD, Marx GM. The implications for mandatory GM labelling under the Consumer Protection Act in South Africa. Food Control. 2013;31(2):387-391. https://doi.org/10.1016/j.foodcont.2012.10.026

6. Gruère GP, Rao SR. A review of international labelling policies of genetically modified food to evaluate India's proposed rule. AgBioForum. 2007;10(1):51-64.

7. South African Freeze Alliance on Genetic Engineering (SAFeAGE). Input for Consumer Protection Bill (CPB). Letter to the portfolio committee of the DTI. 2008 August 08

8. South African Freeze Alliance on Genetic Engineering (SAFeAge). Consumer rights recognised: GM foods will be labelled in South Africa [press release]. 2008 September 17 [cited 2017 Dec 08]. Available from: http://db.zs-intern. de/uploads/1221732671-Safeage-GELabelling.pdf

9. Gosling M. GM labelling clause reinstated in Bill. Cape Times. 2008 September 19 [cited 2013 Feb 20]. Available from: http://www.iol.co.za/index.php?set id =1\&click_id=125\&art_id=vn20080919053532

10. African Centre for Biosafety (ACB). GMO watchdog to lodge complaint [press release]. 2012 March 20 [cited 2014 Jun 15]. Available from: http://www. acbio.org.za/index.php/media/64-media-releases/374-gmo-watchdog-tolodge-complaint

11. Gosling M. Food fight over GMO labelling. Cape Times. 2012 April 10.

12. African Centre for Biosafety (ACB). Industry employing bullying tactics to scupper GM food labelling in South Africa [press release]. 2014 August 01 [cited 2014 Aug 10]. Available from: http://acbio.org.za/wp-content/ uploads/2015/02/GM-Labelling_july_20141.pdf

13. De Beer TL. Stakeholder involvement in the development of genetically modified (GM) food labelling policy in South Africa [dissertation]. Cape Town: University of Cape Town; 2015

14. Paarlberg RL. Governing the GM crop revolution: Policy choices for developing countries. (Food, agriculture, and the environment discussion paper 33). Washington DC: International Food Policy Research Institute; 2000. Available from: http://cdm15738.contentdm.oclc.org/utils/getfile/ collection/p15738coll2/id/125379/filename/125380.pdf

15. Barton JE, Dracup M. Genetically modified crops and the environment. Agron J. 2000;92(4):797-803. https://doi.org/10.2134/agronj2000.924797x

16. Ahmad P, Ashraf M, Younis M, Hu X, Kumar A, Akram NA, et al. Role of transgenic plants in agriculture and biopharming. Biotechnol Adv. 2012;30(3):524-540. https://doi.org/10.1016/j.biotechadv.2011.09.006

17. Scoones I. Mobilizing against GM crops in India, South Africa and Brazil. J Agrar Change. 2008;8(2-3):315-344. https://doi.org/10.1111/j.14710366.2008.00172.x

18. Wynberg R, Fig D. A landmark victory for justice: Biowatch's battle with the South African state and Monsanto. Durban: Biowatch South Africa; 2013.

19. International Service for the Acquisition of Agri-biotech Applications (ISAAA) Biotech country, facts and trends: South Africa [infosheet on the Internet]. Ithaca, NY: ISAA; 2016. Available from: http://www.isaaa.org/resources/ publications/biotech_country_facts_and_trends/

20. Botha GM, Viljoen CD. South Africa: A case study for voluntary GM labelling. Food Chem. 2009;112:1060-1064. https://doi.org/10.1016/j. foodchem.2008.06.050

21. African Centre for Biosafety (ACB). Understanding the impact of genetically modified crops in Africa: An activist's handbook. Johannesburg: ACB; 2012. Available from: http://acbio.org.za/wp-content/uploads/2015/02/ACBActivist-Handbook.pdf

22. Department of Trade and Industry (DTI). Draft Green Paper on the consumer policy framework. Pretoria: DTI; 2004. Available from: https://www.gov.za/ sites/default/files/26774 1.pdf

23. Department of Health (DOH). Viewpoint of the Department of Health on mandatory labelling of foodstuffs containing GMOs [press release]. 2008 September 18
24. Department of Trade and Industry (DTI). Consumer Protection Bill: Response to public submissions [minutes]. Parliamentary Monitoring Group, South Africa; 2008 September 10. Available from: https://pmg.org.za/committeemeeting/9608/

25. South African Freeze Alliance on Genetic Engineering (SAFeAGE). Labelling of products and foods containing GMO's in South Africa [webpage on the Internet]. No date [cited 2012 Mar 17]. Unavailable.

26. Viljoen CD, Dajee BK, Botha GM. Detection of GMO in food products in South Africa: Implications of GMO labelling. Afr J Biotechnol. 2006;5:73-82.

27. Consumer Protection Bill B19-2008. Pretoria: Department of Trade and Industry; 2008. Available from: https://www.thedti.gov.za/parliament/bills/ ConsumerProtectionBill.pdf

28. Department of Trade and Industry (DTI). Consumer Protection Bill: Presentation to the Select Committee on Economic and Foreign Affairs [presentation]. 2008 October 16. Available from: http://slideplayer.com/slide/9866348/

29. Wolson RA. Assessing the prospects for the adoption of biofortified crops in South Africa. AgBioForum. 2007;10(3):184-191.

30. Congress of South African Trade Unions (COSATU). COSATU submission on the Consumer Protection Bill [B19B-2008]. Letter to the Portfolio Committee on Trade and Industry; 2008 September 03.

31. Consumer Protection Act No. 68 of 2008. Government Gazette. 2008;526(32186). Available from: http://www.thedti.gov.za/business regulation/acts/consumer_protection.PDF

32. Woker T. The Consumer Protection Act and genetically modified foods [presentation]. University of KwaZulu-Natal; 2009 Jun 1.

33. Industry Working Group. Industry comments on GM-labelling clause (Clause 24(6)), as included in proposed regulations for Consumer Protection Act (Act Nr. 68 of 2008), as published in Government Gazette, Vol. 545 of 29 Nov 2010, Nr. 33818 [private correspondence with DTI - PAIA request form document]. 2011 January 20.

34. Consumer Goods Council of South Africa (CGCSA). Comments and proposals on regulations required in terms of the Consumer Protection Act [private correspondence with DTI - PAIA request form document]. 2010 September 08 .

35. AfricaBio. Annexure 1: Consumer Protection Act (Act Nr. 68 of 2008) proposed regulations pertaining to Clause 24(6) of the Act (Government Gazette, Vol. 545 of 29 November 2010, Nr. 33818). [Private correspondence with DTI - PAIA request form document]. 2011 January 28.

36. Mohlala M. Request for the Department of Trade and Industry's view on implementation of the genetically modified organisms provisions of the Consumer Protection Act and its regulations. Letter to Rob Davies, Minister of Trade and Industry; 2012 February 10.

37. Bega S. Foot-drag on GM labelling regulations is slammed. Saturday Star. 2012 February 18 [cited 2013 Nov 14]. Available from: https://www. pressreader.com/south-africa/saturday-star/20120218/281612417315437

38. Label GM foods. GM labelling saga update [Facebook post]. 2012 March 26 [cited 2013 Jun 24]. Available from: https://www.facebook.com/ LabelGMFoods?fref $=$ ts

39. African Centre for Biosafety (ACB). Unlabelled food tests positive for GM [press release]. 2012 February 15 [cited 2014 Jun 15]. Available: http:// www.acbio.org.za/index.php/media/64-media-releases/373-unlabelledfood-tests-positive-for-gm

40. Consumer Goods Council of South Africa (CGCSA). Consumer Protection Act (CPA) and its reference to genetic modification (GM) labelling [press release]. 2012 March 16 [cited 2014 Mar 20]. Available: http://www.nestle.co.za/ common/nestleimages/publishingimages/media/press releases/20120316 consumer_protection_act.pdf

41. Vananda N. Request for corrections to be effected on regulation 7: Product labelling and trade description: Genetically modified organisms, of the Consumer Protection Act 68 of 2008. Letter to Rob Davies, the Minister of Trade and Industry; 2012 June 21.

42. Consumer Protection Act (CPA), No. 68 of 2008. Draft amendment regulations: Section 7. Government Gazette 568(35776): Government notice no. R.824. Pretoria: Government Printer; 2012. 
43. Oh J, Ezezika OC. To label or not to label: Balancing the risks, benefits and costs of mandatory labelling of GM food in Africa. Agric Food Sec. 2014;3(8):1-8. https://doi.org/10.1186/2048-7010-3-8

44. Sikuka W. Republic of South Africa: Food and agricultural import regulations and standards - narrative. FAIRS Country Report. Global Agricultural Information Network (GAIN) report. Pretoria: USDA Foreign Agricultural Service; 2015

45. Freidberg SE, Horowitz L. Converging networks and clashing stories: South Africa's agricultural biotechnology debate. Afr Today. 2004;51(1):3-25. https://doi.org/10.1353/at.2004.0063

46. Morris EJ, Thomson JA. Genetically modified crops commercialized in South Africa. In: Wambuga F, Kamanga D, editors. Biotechnology in Africa: Emergence, initiatives and future. Cham, Switzerland: Springer; 2014. p. 53-65. https://doi.org/10.1007/978-3-319-04001-1_4

47. Reed MS. Stakeholder participation for environmental management: A literature review. Biol Conserv. 2008;141(10):2417-2431. https://doi. org/10.1016/j.biocon.2008.07.014

48. Rowe G, Frewer LJ. Public participation methods: A framework for evaluation. Sci Technol Hum Val. 2000;25(3):3-29. https://doi. org/10.1177/016224390002500101

49. Innes JE, Booher DE. Reframing public participation: Strategies for the 21st century. Plan Theory Pract. 2004;5(4):419-436. https://doi. org/10.1080/1464935042000293170

50. Parkins JR, Mitchell RE. Public participation as public debate: A deliberative turn in natural resource management. Soc Nat Resour. 2005;18(6):529-540. https://doi.org/10.1080/08941920590947977
51. Dür A, De Bièvre D. The question of interest group influence. J Public Policy. 2007;27(1):1-12. https://doi.org/10.1017/S0143814X07000591

52. Aerni P. Stakeholder attitudes towards the risks and benefits of genetically modified crops in South Africa. Environ Sci Policy. 2005;8(5):464-476. https://doi.org/10.1016/j.envsci.2005.07.001

53. Herian MN, Hamm JA, Tomkins AJ, Zillig LMP. Public participation, procedural fairness, and evaluations of local governance: The moderating role of uncertainty. J Public Adm Res Theory. 2012;22(4):815-840. https://doi. org/10.1093/jopart/mur064

54. Richards C, Blackstock KL, Carter CE. Practical approaches to participation. SERG policy brief no. 1. Aberdeen: Macauley Land Use Research Institute; 2004.

55. Weber N, Christophersen T. The influence of nongovernmental organisations on the creation of Natura 2000 during the European policy process. Forest Policy Econ. 2002;4(1):1-12. https://doi.org/10.1016/S13899341(01)00070-3

56. Reed MS, Graves A, Dandy N, Posthumus H, Hubacek K, Morris J, et al. Who's in and why? A typology of stakeholder analysis methods for natural resource management. J Environ Manage. 2009;90(5):1933-1949. https:// doi.org/10.1016/j.jenvman.2009.01.001

57. Lynam T, De Jong W, Sheil D, Kusumanto T, Evans K. A review of tools for incorporating community knowledge, preferences, and values into decisionmaking in natural resources management. Ecol Soc. 2007;12(1), Art. \#5, 15 pages. https://doi.org/10.5751/ES-01987-120105

58. African Centre for Biosafety (ACB). Comments on the draft government notice on the consumer protection general regulations [private correspondence with DTI - PAIA request form document]. 2010 August 30. 